\title{
THE IMPACT OF TRIPS AGREEMENT ON ACCESS TO MEDICINES IN DEVELOPING COUNTRIES: LEGAL CHALLENGES FACED BY THE PHARMACEUTICAL INDUSTRY PARTICULARLY IN INDIA
}

\author{
Kamini Shanmugaiah ${ }^{1}$
}

\begin{abstract}
The impact of intellectual property rights in particular patent relating to public health has posed numerous challenges faced by developing countries who are members of World Trade Organisation (WTO). This paper examines the impact of TRIPS Agreement (Trade Related Intellectual Property Rights) in relation to developing countries in general with specification made to India. Significant changes brought about by the TRIPS flexibilities in particular usage of compulsory licensing and Bolar provision have to a certain extent benefited the developing countries in the field of public health during national emergency. The TRIPS flexibilities by way of amendment have helped countries that (do not possess manufacturing capacities) to import medicines. Some developing countries even utilised TRIPS flexibilities in an aggressive manner to enforce their right to have access to medicines from other countries for the benefit of their citizens. Further, TRIPs flexibilities have helped developing countries to manufacture generic products to make it affordable to the people. This paper specifically examines the impact of the TRIPS Agreement on Indian generic pharmaceutical industry and the legal challenges faced by Indian pharmaceutical industry after the implementation of product patent regime effective from 1 January 2005. The Patent Amendment Act 2005(India) will be looked into especially on the controversy in respect of Section 3(d) of the Patent Amendment Act 2005(India) on the requirement of patentability. The new Section 92A of the Patent Amendment Act 2005(India) on the grounds to invoke compulsory licensing will be analysed to see whether Indian government has applied restrictive or broad approach, as compulsory licensing is certainly an important legal

1 Lecturer, College of Law Government and International Studies, Universiti Utara Malaysia, 06010, Sintok, Kedah. Tel 04-9284695, Fax 04-9284205, E-mail: kamini@uum.edu.my; minnieshan82@yahoo.co.uk
\end{abstract}


weapon for India to manufacture affordable generic medicines. The current challenges faced by India on data exclusivity provision often described as the TRIPS PLUS standard is impliedly stated in Article 39.3 of the TRIPS Agreement on undisclosed information. India needs to achieve legal certainty in complying with the TRIPS Agreement and also bearing in mind the TRIPS-PLUS standards before adopting those TRIPS provisions into its patent law legislation in order to promote innovation and to achieve public health as well as to serve the interest of the developing countries.

Keywords: TRIPS flexibilities, Compulsory Licensing, Article 39.3 on undisclosed information, Indian Patent Act 1970, Patent Amendment Act 2005: Section 3(d), pre and post grant opposition

\section{Introduction}

Modern science and technology medicine have made available many new drugs to cure and manage various ailments. Unfortunately, the question is on the drugs people can afford which are too expensive for individuals and governments to buy. Apart from that, there is also intellectual property concern and patented medicines. ${ }^{2}$ According to Christophe Weber, GlaxoSmithKline's senior vice president and regional director of Asia Pacific, one of the challenges faced is the higher prices of drugs due to the pharmaceutical industry's research and development business model. ${ }^{3}$ The essential point relevant to the initial introduction is access to affordable medicines in the developing countries through generic competition and access to cheaper medicines of assured quality. ${ }^{4}$

In relation to this study, the author will be looking into mainly the legal analysis in the context of TRIPS (Trade-Related Intellectual Property Rights) and the adoption and implementation of TRIPS Agreement into the national patent law of developing countries. Compulsory licensing use by developing countries like Thailand, Brazil, Malaysia will be looked into as well. These countries are chosen because they have used the system of compulsory licensing

2 The Star Newspaper, national edition (Malaysia). 2010. December 19.

3 Ibid.

4 Ibid 
either to manufacture or import generic medicines. Compulsory licensing is a mechanism allowed under TRIPS which increases access to generic drugs. ${ }^{5}$ The actual essence of the TRIPS Agreement will be analysed, as to whether TRIPS is a legal weapon to protect the right of the patentee exclusively balancing between patent holder rights and public health objectives in relation to accessibility and affordability of medicines in the developing countries.

In addition, other challenges that will be faced by developing countries such as India are whether there is sufficient technology transfer in relation to pharmaceutical patent referring to Article 66.2 of the TRIPS Agreement which encourages member countries to promote technology transfer. The patentee who wishes to establish manufacturing plant in producing pharmaceutical products must be willing to conduct knowledge transfer in terms of medical innovation and mere setting up the manufacturing plant is not sufficient. The three (3) requirements of obtaining a patent or patentability such as novelty, inventive step and capable of industrial application must be looked into. The three (3) requirements of patentability are very much related to the issue of evergreening of patent as member countries are given much flexibility to draft their own patent law according to their need in terms of economic and technological development. The requirement of patentability should not merely follow the guidance under the TRIPS Agreement on Article 27(1) but should be implemented according to the needs of each member state in a reasonable manner.

Besides that, the pre and post grant opposition need to be looked into revocation and granting the patent itself is not given much attention compared to the limitation to the exclusive rights of patent holder such as the TRIPS flexibilities. In the author's view, discrimination should be avoided in the interest of developing countries when it comes to determining the grounds to invoke the compulsory licensing as the national sovereignty in the usage of TRIPS flexibilities should be respected by the big pharmaceutical companies (North counterpart).

5 Can TRIPS Deliver, Patent Pills and Public Health, ed. Martin Foreman, in the Panos Institute, dspace.cigilibrary.org/jspui/bitstream/123456789/14574/1/... (accessed April 20, 2013). 
Although price factor is highly a significant one, however in order to achieve a balance between affordability of medicines and medical innovation is certainly a challenging one. The implementation of the TRIPSAgreement into the domestic patent legislation at least provides hope for the developing countries in terms of the technology transfer which will enable the domestic generic pharmaceutical industry to sustain in the production of new medicines. ${ }^{6}$ In the author's view, strong will of the country to promote healthy competition between generic and big pharmaceutical companies to ensure accessibility and affordability to serve the public interest can be shown in the implementation of TRIPS flexibilities such as compulsory licensing and Bolar provision effectively.

It is certainly important to take note of the implied exception under Article 39(3) which states that members shall protect such data against disclosure, except where necessary to protect the public or unless steps are taken to ensure that the data are protected against unfair commercial use. In the author's view, the stringent condition imposed in Article 39(3) on the data exclusivity against disclosure and trade secret of the invention itself can be prevented with the effective implementation of the Bolar provision and compulsory licensing in the patent law itself, being one of the TRIPS flexibilities will facilitate the weaknesses that existed in the Article 39(3). The effective utilization of Bolar provision or said as regulatory provision can be seen from Canada's experience itself as The World Trade Organisation Panel in Canada on Patent Protection for Pharmaceutical Products decided that this provision, allowing limited exceptions, covered a provision of Canadian law which permits the use by generic producers of patented products, without authorization and prior to the expiry of the patent term, for the purposes of seeking regulatory approval from public health authorities for the marketing of their generic version as soon as the patent expires.?

6 Quaker International Affairs Programme, How Strong Patent Protection Affects Access to Medicines Patents, ed. Jonanthan Hepburn, in the Ottawa and Quaker United National Office Geneva, http:/www.iprsonline.org/resources/health. htm (accessed April 20, 2013).

7 World Trade Organisation, "Pharmaceutical Patents and TRIPS Agreement, http://www.wto.org/english/tratop_e/trips_e/pharma_ato186_e.htm (accessed April 1, 2013). 


\section{The TRIPS Agreement Related to Access of Medicines on Public Health Matters}

Under this heading, the relationship between TRIPS Agreement and public health will be analysed. First and foremost, Article 30 of the TRIPS Agreement will be looked into, which provides for limited exceptions to the exclusive rights conferred by a patent provided that such exceptions do not unreasonably conflict with the exploitation of the patent and do not unreasonably prejudice the interest of the patent owner, taking into account the legitimate interests of the third parties. ${ }^{8}$ The issue that the author would like to address is on what is actually meant by "do not unreasonably conflict with a normal exploitation of a patent and also the statement on 'unreasonably prejudice the legitimate interest of the patent owner. A question is bound to arise here as to what is meant by the reasonable means to be taken by generic companies who wishes to exercise their rights.

Article 30 of the TRIPS Agreement indicates that generic companies have to negotiate with the patent holder on case to case basis according to their needs. Furthermore, if we read Article 30 provision on 'taking account of the legitimate interest of third parties carefully,' it implies to the author that a strict approach is imposed with less significance imposed on the rights of third parties such as the generic pharmaceutical companies who wishes to exploit the patented invention as the main objective of Article 30 should focus on the limitation of the right given to the patent owner and clearly explain the if the negotiations fails between generic producer and patentee and then Article 30 can be disregarded. Besides, we can also state that Article 30 is the first provision of TRIPS Agreement that initiates the exceptions to the monopoly rights given to the patentee. Subsequently, the importance on the limitation of the rights of the patentee can be further appreciated and seen in the important provision of Article 31 on the other use without authorisation of the right holder, which is often called as compulsory licensing. Under Article 31, government may issue a compulsory licensing authorising third party to produce generic drugs without

8 Paul Goldstein, International Legal Materials on Intellectual Property (United States: Foundation Press, 2006), 14. 
authorisation of the patent holder where negotiations fail to obtain authorisation on reasonable commercial terms. ${ }^{9}$

The compulsory licensing provision under Article 31 is certainly an important legal weapon in relation to access to medicines in developing countries including India which is frequently discussed by different researchers and authors in relation to patent protection, TRIPS and developing countries. ${ }^{10}$ As many developing countries do not have the capacity to manufacture generic drugs and TRIPS has given some flexibilities for countries lacking manufacturing capacity by having TRIPS Declaration on Paragraph 6 which acknowledges the inadequacy of manufacturing capacity with respect to compulsory licensing. Referring to paragraph 6, which states that 'We recognise WTO members with insufficient or no manufacturing capacities in the pharmaceutical sector could face difficulties in making effective use of compulsory licensing under the TRIPS Agreement and we instruct the Council for TRIPS to find an expeditious solution to this problem. Paragraph 6 waives an exporter's Article 31(f) obligation to supply predominantly to the domestic market, enabling any country with manufacturing capacity to issue a compulsory licence to produce generic drugs for export to countries that have insufficient or manufacturing capacity, subject to several conditions. ${ }^{11}$ However, in order to invoke Article 31(f) waiver to produce generic medicines, a proper implementation of compulsory licensing provision is important.

\section{Compulsory Licensing: A Potent Legal Weapon}

Frederick M. Abbott, an eminent scholar in the field of International Law defines compulsory license as a 'legal vehicle whereby a government grant to itself or to a third party the right to manufacture or to import patented product without authorisation of the patent holder or the right holder'. ${ }^{12}$ Importantly, the question raises on

9 Bradly J Condon and Tapen Sinha, Global Lessons from the AIDS Pandemic: Economic, Financial, Legal and Political Implications (Germany: SpringerVerlag Berlin Heidelberg, 2008), 14.

10 Duncan Matthews, Globalising Intellectual Property Rights: The TRIPS Agreement (New York: Rutledge Warwick Studies in Globalisation, 2002), 121.

11 Condon and Sinha, Global Lessons from the AIDS Pandemic, n. 9 at 14.

12 Frederick M Abott and Rudolf V.Van Puymbroeck, Compulsory Licensing for Public Health: A Guide and Model Documents for Implementation of the Doha Declaration Paragraph 6 Decision (World Bank Working Paper No. 61 Global HIV/AIDS Programme, 2005), 35. 
which ground of public health problems compulsory licensing can be issued and paragraph 1 of the Doha Declaration is given main priority on the public health problems and applied to the main utilisation of compulsory licensing. The definition on public health problems as recognised in paragraph 1 of the Declaration provides that: 'We the Doha Ministerial Conference recognise the gravity of the public health problems afflicting many developing and least developed countries, especially those resulting from HIV/AIDS, tuberculosis, malaria and other epidemics. ${ }^{13}$ Importantly, public health problems or scope of diseases of developing and least-developed country members are not limited to the HIV/AIDS, tuberculosis, malaria and other epidemics. ${ }^{14}$

According to paragraph 5(c) of the Doha Declaration which states 'each member has the right to determine what constitutes a national emergency or other circumstance of extreme urgency and further expressly acknowledges that HIV/AIDS can constitute a national emergency or circumstance of extreme urgency..$^{15}$ The issues that need to be addressed are whether on the conditions relating to other circumstances of extreme urgency, whether it should include non-communicable diseases such as cancer, diabetes, heart and lung disease which are said to be the $21^{\text {st }}$ century's greatest health challenge. ${ }^{16}$ At the press conference to preview UN summit in September, John Seffrin the chief executive officer of the American Cancer Society said that by 2030 non-communicable diseases were expected to cause five times as many deaths as communicable diseases world-wide. Furthermore, as stated by the UN Secretary General Ban Ki Moon international community had focused on communicable diseases such as HIV/AIDS, malaria and tuberculosis, and four main non-communicable diseases have emerged relatively unnoticed in the developing world which are now becoming global epidemic. ${ }^{17}$ In order to have a clear and straightforward legal implementation of compulsory licensing provision or to make compulsory licensing an important legal weapon, the basic grounds on the scope of diseases in achieving the overall objective of health problems should be clearly

13 Abott and Puymbroeck, Compulsory Licensing for Public Health, 35.

14 Abott and Puymbroeck, Compulsory Licensing for Public Health, 35.

15 Abott and Puymbroeck, Compulsory Licensing for Public Health, 35.

16 The Star Newspaper, national edition.2011.June 22.

17 Ibid. 
addressed without being ambiguous or causing further procedural difficulties to the generic companies to manufacture medicines for the need of domestic market and other developing countries.

Compulsory licensing need to be used aggressively with a clear adoption of the requirement concisely as possible into the national patent legislation in order to address overall health problems that leads to death which affects the global economy. Importantly, in relation to the TRIPS Agreement one of the significant flexibilities can be seen in the Doha Declaration on paragraph 5(b) which states 'each member has the right to grant compulsory licenses and the freedom to determine the grounds upon which such licenses are granted. ${ }^{18}$ So grounds on compulsory licensing should not be used restrictively. ${ }^{19}$ As we can observe, compulsory license is often issued only when patented invention is not available to the public at a reasonable price and on the grounds of working the patented invention for the domestic generic pharmaceutical industry.

\section{A Case Study on India: Is India Fully Utilising Compulsory Licensing or Undermining the Usage?}

Referring to the case study on India, compulsory licensing is so far only used for manufacture and export of patented pharmaceutical products to the country having insufficient or no manufacturing capacity in the pharmaceutical sector for the concerned product in order to address public health problems. ${ }^{20}$ For instance, the author is of the view that data relating to compulsory licenses for the use in India is not available, which will be addressed later in the process of author's thesis on the reason why India has not invoke other grounds such as reasonably requirement of the public, invention not available to the public at a reasonable affordable price, and national working of patent when it was explicitly allowed in the Patent Act 1970 and Patent Amendment Act 1999. Referring back to the compulsory licensing granted during the public health crisis

18 Frederick M. Abott; "Doha Declaration on the TRIPS Agreement and Public Health: Lighting A Dark Corner At The WTO," Journal of International Economic Law 469 5, no. 2 (2002): 469.

19 Abott, "Doha Declaration on the TRIPS Agreement and Public Health," 469.

20 Kalyan C Kankala et al., Indian Patent Law and Practice (India: Oxford University Press, 2010), 180. 
in Malaysia, Thailand and Ghana, India had issued compulsory licensing for export which can be seen in the amendment of Patent Amendment Act 2005(India), as the decision on para 6 of the Doha Declaration which permitted WTO members to allow export of pharmaceutical product to other developing and underdeveloped countries not having manufacturing capacities to deal with the public health problems can be seen in the new section $92 \mathrm{~A}$ in the Patent Amendment Act 2005(India) for compulsory licensing for export of patented pharmaceutical products in certain exceptional circumstances. ${ }^{21}$

In relation to compulsory licensing for export in India being exporting country, Thailand granted a compulsory licence for importation and local production of efavirenz used for ARV therapy and the licence was granted by Thailand Ministry of Health on 29 November 2006 and initially royalty proposed for patent holder was 0.5 percent. After the grant of compulsory licence, Ranbaxy, an Indian pharmaceutical company supplied amount of 66,000 bottles of the generic version of efavirenz to Thailand. Importantly, the issuance of the licence by the government at a reduced cost of ARV drugs by 50 percent and increase the accessibility to 20,000 persons was well received. Subsequently, companies like Merck reduced the cost of the price of their ARV drugs. ${ }^{22}$

Compulsory licensing is said to be an important legal tool to ensure access to affordable medicines and its importance and usage were reaffirmed in the 2001 Doha Declaration on the TRIPS Agreement and Public Health. By way of making reference to the Thailand's Patent Act 1999 in comparison with the Indian Patent Act 1970, the Thailand Patent Act 1999 in Section 51 states that any ministry, bureau or department of the Government may, by themselves or through others, exercise the compulsory licensing right " in order to carry out any service for public consumption or which is of vital importance to the defense of the country or for the preservation or realisation of natural resources or the environment or to prevent or relieve a severe shortage of foods, drugs or other consumption items

21 The Patents ( Amendment Act 2005) <http::ipindia.nic.in/ipr/patent/patents. htm $>$ (accessed July 6, 2011)

22 Kankala et al., Indian Patent Law and Practice, n. 20 at 183. 
or for any other public service. ${ }^{23}$ Another example when Malaysia granted a compulsory licensing on antiretroviral (ARV) drugs for treatment of AIDS on 29 September 2004, authorisation being valid for two years whereby involving importation of listed drugs such as didanosine $(100 \mathrm{mg})$, didanosine $(25 \mathrm{mg})$, zidovudine $(100 \mathrm{mg})$ and lamivudine+zidovudine $(150 \mathrm{mg})$ from Cipla, India. ${ }^{24}$ After the grant of compulsory licence the cost of ARV drugs reduced by 81 per cent and the treatment programme of the government was increased to 4,000 patients from 1,500 patients. The compulsory licence granted by the Malaysian government proved to be effective for implementing the AIDS treatment programme and making drugs more accessible. ${ }^{25}$

In the author's view, respective country concerned should use compulsory licensing as a potent or a powerful legal weapon to meet their public health objectives, as we can see the example of Malaysia on the importation of AIDS drugs is concerned. India being the major exporter of pharmaceutical drugs to the developing countries and having a strong generic pharmaceutical industry should utilise the compulsory licensing mechanism to the development of the generic pharmaceutical industry as in terms of improving the technology transfer and not merely focusing for export purposes, and affordability of medicines.

The reason is because India needs a sufficient technology transfer from developed countries which are the original patent holder. In order to have self reliant domestic generic pharmaceutical industry and capability to develop new chemical entities without relying on reverse engineering, the invention of a sufficient technology transfer becomes very vital. For instance, grounds to invoke compulsory licencing such as reasonable requirement of the public are not satisfied on whether development of commercial activities in India is prejudiced ( referring to Section 90A), and on grounds invention not being worked in India which will assist the generic pharmaceutical

23 Third World Network, "Thailand Issues compulsory licence for cheaper AIDS Drugs," 2006.

http://www.twnside.org.sg11P health reports.htm (accessed July 5, 2011).

24 See http://www.cpteh.org/ip/health/c/malaysia/arv-licence.html (accessed July 5, 2011).

25 Kankala et al., Indian Patent Law and Practice, n. 20 at 182. 
industry. ${ }^{26}$ The grounds of compulsory licensing should address effective transfer of technology and one way is through national working of patent as 3 years period given to invoke as to monitor whether invention is worked effectively and not neglecting the fact on the 3 years period which is said to be too lengthy. As through the observation on the grounds for compulsory licensing for government use such as national emergency or other circumstances of extreme urgency is frequently used and the question is whether because of the reaffirmation of the Doha Declaration on the TRIPS Agreement and Public Health. Besides that though Articles 7,8 and 31 of the TRIPS Agreement clearly intend to extend social benefits of patents to areas other than those provided under the Paris Convention, however as authorised by Article 5A each member has the right to adopt legislative measures to prevent abuses of a patent holder's exclusive rights. ${ }^{27}$ Although term of failure of work is not to be clearly defined by the Paris Convention, ${ }^{28}$ the national patent law of respective country's legislation can interpret 'failure to work' in their own definition as failure to transfer technology to generic pharmaceutical industry.

\section{Compulsory Licensing in India: The Most Comprehensive Non- Voluntary Licensing System}

Compulsory licensing under the Indian patent law is said to be the most comprehensive non-voluntary licensing system in the world. ${ }^{29}$ For instance, this statement applies especially to section 84, as the compulsory licence may be granted to prevent abusive practices by patent holder or to prevent patent holder using patents to block commercial exploitation of the patented invention. The law in India allows any person to apply for a compulsory licence due to a failure to work the patented invention in India in three years from date of issuance of patent. The burden of proof lies with the applicant

26 Patent Office India, “The Patents Act 1970 (39 of 1970) (As Amended By the Patents Amendment Act 1999 :effective from $1^{\text {st }}$ 1995, http://ipindia.nic.in/ipr/ patent/patents.htm (accessed July 5, 2011).

27 Jakkrit Kuanpoth, Rights in Pharmaceuticals in Developing Countries: Major Challenges or the Future (United Kingdom: Edward Elgar Publishing, 2010), 34.

28 Kuanpoth, Rights in Pharmaceuticals in Developing Countries: Major Challenges or the Future, 31.

29 Kuanpoth, Rights in Pharmaceuticals in Developing Countries: Major Challenges or the Future, 167. 
for compulsory licensing which need to prove non-working of the patented invention in the country or the unavailability to the public of the patented invention at a reasonably affordable price. ${ }^{30}$ However, the question is whether failure to work means failure to set up manufacturing plant of big pharmaceutical companies in India or failure to disclose patented invention fully or insufficient transfer of knowledge of the technological part of the invention. The practice of compulsory licensing may have its drawbacks, as it may be difficult for developing countries to establish a local manufacturing facility capable of exploiting the invention, and foreign companies may be reluctant to invest in developing countries, further internal procedures for granting compulsory licensing might not have been put in place. ${ }^{31}$ The argument against the application TRIPS flexibilities such as compulsory licensing implies to us that Indian legislation is going back to the history before implementation of product-patent protection., This is because India is merely reverseengineering or exploiting the invention with limiting the patent holder rights. The discussion of the author and study on this topic revolves around the issue of whether the grounds of compulsory licensing and the 3 requirements of patentability in the Indian patent law are complied with as according to the TRIPS Agreement, but none surprisingly clearly discussed on the disclosure requirement of the patentee invention or whether sufficient disclosure exist in the first place in the patentee invention in order for India to exploit the invention to the development of their generic industry as patent is a price for disclosure which need to be given significant priority in the TRIPS Agreement.

Articles 7 and 8 of the TRIPS Agreement: Ultimate Objective Promoting Technology Transfer or Merely an Exception to Article 27 of the TRIPS

The definition of Articles 7 and 8 of the TRIPS Agreement can be seen as follows: Article 7 of the TRIPS states: 'The protection and enforcement of intellectual property rights should contribute to the promotion of technological innovation and to the transfer and

30 Kuanpoth, Rights in Pharmaceuticals in Developing Countries: Major Challenges or the Future, 168.

31 Duncan Matthews, Globalising Intellectual Property Rights: The TRIPS Agreement (New York: Rutledge Warwick Studies in Globalisation, 2002), 121. 
dissemination of technology, to the mutual advantage of producers and users of technological knowledge in a manner conducive to social and economic welfare, and to balance of rights. ${ }^{32}$ Besides that, Article 8 goes further to state: "members may in formulating or amending their laws and regulations, adopt measures necessary to protect public health and nutrition, and to promote the public interest in sectors of vital importance to their socio-economic and technological development provided that such measures are consistent with TRIPS Agreement. ${ }^{33}$ From Articles 7 and 8 of the TRIPS Agreement, we can observe that TRIPS Agreement gives importance to the national interest of each respective country in implementing or amending their laws accordingly. The use of the mechanism of compulsory licensing is another alternative route to produce generic medicines and indicates a pre-adoption of TRIPS Agreement before implementation of product patent protection in 2005 by India, and this certainly is not an ultimate solution for India as should be striving for the excellence in the development of medical technologies in relation to the generic pharmaceutical industry.

\section{Article 27.1 of the TRIPS Agreement: Another Legal Challenge to the Generic Industry in India}

Another major legal challenge faced by India is on the issue of compatibility with Article 27 of the TRIPS Agreement regarding to the patentability requirement.. According to Article 27(1) subject to the provisions of paragraph 2 and 3, patents shall be available for any inventions, whether product such as medicine and processes on method of producing chemical entities, in all field of technology, provided that they are new or novelty, involves an inventive step as of not obvious and are capable of industrial application (must be useful). ${ }^{34}$ So, the question is whether the Indian Patent Act 1970 and the Indian Patent Amendment Act 2005 by virtue of referring to Section 3(d) complies with Article 27 (1) of the TRIPS Agreement.

32 Christophe Bellmann et al., Trading In Knowledge: Development Perspectives on TRIPS, Trade and Sustainability (United Kingdom: Earthscan, 2003), 149.

33 Bellmann et al., Trading In Knowledge: Development Perspectives on TRIPS, Trade and Sustainability, 31.

34 See http://www.wto.org/english/tratop_e/trips_e/factsheet_pharm02_e.htm \#eligibility (accessed July 5, 2011) 
In relation to Section 3(d) and its effect to the domestic generic pharmaceutical industry, it is important to note that the same standard of patentability needs to be adopted without discrimination as to the place of the invention, the field of technology and whether the products are imported or locally produced. ${ }^{35}$

\section{The Validity of Section 3(d) of The Patent Amendment Act 2005 (India) with the TRIPS Agreement: India's Post-TRIPS Challenge}

Firstly, looking into the amendment of Section 3 in the Patent AmendmentAct 2005 which states explicitly that "the mere discovery of a new form of a known substance which does not result in the enhancement of the known efficacy of that substance or the mere discovery of any new property or new use for a known substance or of the mere use of a known process, machine or apparatus unless such known process result in a new product or employs at least one new reactant and for the purpose of this clause, salts, esters, ethers, polymorphs, metabolites, pure form, particle size, isomers, mixtures of isomers, complexes, combinations and other derivatives of known substance shall be considered to be the same substance, unless they differ significantly in properties with regard to efficacy." ${ }^{36}$ So mere discovery of a new form, or new use or new property of a known substance is not patentable, and the discovery of the new form of a known substance will be patentable only if it results in the enhancement of the known efficacy of that substance.

The word 'efficacy' has created legal uncertainty and efficacy is said to be shown by the improved effect in comparison with the original substance through objective scientific evidence. For example, existence of calcium in carbonate form is well known, discovery of its existence in a sulphate form would not amount to patent grant, unless calcium in sulphate form has an improved effect when compared to the carbonate form. ${ }^{37}$ Perhaps it is vital here to make reference to the Patent Amendment Act 2005, which states that mere use of a known process is not patentable unless such process results

35 Goldstein, International Legal Materials on Intellectual Property, n. 8 at 14.

36 The Patents (Amendment Act 2005) http::ipindia.nic.in/ipr/patent/patents.htm (accessed July 3, 2011)

37 Kankala et al., Indian Patent Law and Practice, n. 20 at 182. 
in new product or employs at least one new reactant. For example, discovery of the use of Aspirin for treating cardiovascular diseases would not be patentable, if it was already being used as an analgesic. ${ }^{38}$ The efficacy referred to is an analgesic which is commonly used in aspirin (g.v) or acetylsalicylic acid, which reduces fever and relieves inflammation, as well as lessening pain. ${ }^{39}$ The discovery of Aspirin to treat cardiovascular disease for instance, another form of usage of Aspirin, which in the author's opinion also includes therapeutic methods for treatment of humans. As according to Article 27(3) (a) on patentable subject matter, members may also exclude from patentability the diagnostic, therapeutic and surgical methods for the treatments of human and animals. ${ }^{40}$

Importantly, Section 3(d) of the Indian Patent Amendment Act 2005 has become a landmark pharmaceutical case study which has caused much controversy. The question that is much debated is whether Section 3(d) is compatible with the TRIPS Agreement. The constitutional validity and application of Section 3(d) was challenged by Novartis before the Madras High Court in the case of Novartis AG v Union of India, as in that Novartis filed for a patent over Imatinib Masylate, which was a salt form of the patented molecule, Imatinib Masylate also called as Glivec is used for cancer treatment. ${ }^{41}$ Novartis challenged the Madras High Court on three grounds:

1) That Section 3(d) of the Patent Act 2005 is unconstitutional on the ground that it violates Article 14 of the Constitution of India on the equality before the law, as it is said to discriminate against the pharmaceutical sector with other technology sector.

2) The new Section 3(d) is in violation of the India's obligation as a signatory to the TRIPS under Article 1(1) and Article 27.

3) That Section 3(d) was vague and arbitrary that a discovery becomes an invention if the substance in question results in enhancement of known efficacy is a very ingenious concept.

38 Kankala et al., Indian Patent Law and Practice, n. 20 at 182.

39 See http://www.britannica.com/facts/5/213/47/aspirin-as-discussed -in-analgesic-drug (accessed July 8, 2011)

40 See http://www.wto.org/english/tratop_e/trips_e/factsheet_pharm02_e.htm \#eligibility (accessed July 8, 2011)

41 Kankala et al., Indian Patent Law and Practice, n. 20 at 182. 
To summarize, the above case was divided into three parts: i) patentability of Glivec; ii) the compliance of the Patents (Amendment) Act 2005 with TRIPS and iii) constitutional validity of Section 3(d) of Patents Act 1970 as amended by the Patents Amendment Act ( India). ${ }^{42}$ Interestingly, looking into the brilliant argument made by the Assistance Controller of Patents And Designs in the decision of the Madras High Court on the Novartis challenge and upheld the validity of Section 3(d) of the Patents Act 1970 ( as per amended) in 2005. It was stated by the Assistance Controller of Patents and Designs, India being a welfare and developing country, which is predominantly occupied by people below poverty line, and has a constitutional duty to provide good health care to its citizens by giving them easy access to life-saving drugs. The justification is to prevent "evergreening of a patent" by allowing generic medicine to be available in the market. Section 3(d) also sets an 'obviousness standard' and member states are free to define the standard in a manner consistent with their national policy. The court also held that the amended section was not in violation of Article 14 of the Constitution of India. ${ }^{43}$ Section 3(d) of the Patents Act 1970 as amended by the Patents (Amendment) Act 2005 (India) does not discriminate against the pharmaceutical sector but only makes a justified differentiation, given the specificity of salt forms in the pharmaceutical sector as technological sectors such as mechanicals and electronics does not face issues arising from different salt forms. ${ }^{44}$ Besides that, Indian Patent Amendment Act 2005 also further added to the non-obviousness requirement as to a technical advancement and economic significance. ${ }^{45}$ The amendment also denies secondary patents unless it would therapeutically significant, ${ }^{46}$ as Patent Amendment Bill 2005 was introduced in the Parliament in March 2005 the objective of making the Patents Act compatible with Indian

42 Thomas Pogge et al., Incentives for Global Public Health: Patent Law and Access to Essential Medicines (Cambridge: Cambridge University Press, 2010), 393.

43 Pogge et al., Incentives for Global Health, 393.

44 Pogge et al., Incentives for Global Public Health, 393.

45 Maria Comune, Health Innovation from and for the South? 'The TRIPS Agreement and pharmaceutical industry in India (Germany: Lambert Academic Publishing, 2010), 40.

46 Comune, Health Innovation from and for the South, 40. 
international obligations, particularly under the TRIPS.). ${ }^{47}$ Further Consideration on Clause 3(d) of Indian Patent Amendment Act 2005: The Mashelkar Report state that the incremental innovations are sequential developments that build on the original patented product which may be of tremendous or significant value in a country like India. ${ }^{48}$

Dr R.A Mashelkar, the Director General on the Council of Scientific and Industrial Research argued that many Indian companies are filing patent applications abroad for incremental innovations and also of the opinion that by restricting patent protection only to totally new molecules (new chemical entities) would deprive them of the chance to create intellectual property. ${ }^{49}$ However, it was well explained by the author that a substance obtained by mere admixture resulting only in the aggregation of the properties of the compounds or a process of producing such substance is not patentable. In contrary if the admixture produces a synergistic effect of properties of the components the substance would be patentable. For instance, an admixture of Ibuprofen and Paracetamol to cure pain and fever would not be patentable, because it is an admixture in which Ibuprofen and Paracetamol are aggregated and work independently on pain and fever. However, an admixture of Amoxycilin and Clavulonic acid for respiratory disorders would be patentable because the admixture produces a synergistic effect and results in better action and efficiency. ${ }^{50}$

Furthermore, Dr Mashelkar also had drawn a distinction between evergreening and incremental innovation on the ground that the distinction between evergreening and incremental innovation. Evergreening refers to extension of patent monopoly achieved by executing trivial and insignificant changes to an already existing patented product and incremental innovations are sequential developments that build on the original patented product and may contribute significant value to the country like India as stated earlier. ${ }^{51}$

47 Controller General of Patents Designs and Trademarks (CGPDTM), "Report of the Technical Expert Group on Patent Law, http://ipindia,nic.in/ipr/patent/ patents.htm (accessed July 5, 2011).

48 M B Rao and Manjula Guru, Patent Law in India (Netherlands: Kluwer Law International, 2010), 39.

49 Rao and Guru, Patent Law in India, 40.

50 Kankala et al., Indian Patent Law and Practice, n. 20 at 19.

51 Rao and Guru, Patent Law in India, n. 49 at 40. 
The Dr Mashelkar technical expert committee report also stated that it would not be WTO compliant to limit granting of patents for pharmaceutical substance to new chemical entities, meaning that incremental innovation must be allowed. ${ }^{52}$ Although there are allegations that Indian patent system is too liberal in practice, ${ }^{53}$ in the author's view even in Article 27 of the TRIPS Agreement itself it does not explain further on the elements of novelty or new, involve an inventive step and capable of industrial application. This argument is also well supported by paragraph 4 of the Doha Declaration on TRIPS Agreement and Public Health adopted on 14 November 2001 which states TRIPS Agreement should be interpreted and implemented in a manner to protect public and to promote access of medicines to all and further to note on matter of fact that in Article 3 of the Doha Declaration it states intellectual property protection is important for the development of new medicines. ${ }^{54}$ This indicates to the author that the development of new medicines with significant changes should be encouraged in order to achieve the objective of Article 66.2 of the TRIPS Agreement which states that developed country members shall encourage knowledge in terms of medical technology to least-developed members in order to enable them to create a sound technological base. ${ }^{55}$ So in the author's view one effective way of encouraging technology transfer is through sufficient disclosure of the invention of the patent in order for generic companies to fully utilise TRIPS flexibilities such as compulsory licensing to exploit the invention to meet their public health objectives.

The question is whether the Indian Patent Amendment Act 2005 is not clear enough on the issue of what is not an invention. To the author, this is because of Article $29^{56}$ relating to conditions on patent applicants which states 'members shall require that an applicant for a patent to disclose the invention in a manner sufficiently clear and complete for the invention to be carried by a person skilled in the art

52 Rao and Guru, Patent Law in India, n. 49 at 40.

53 Rao and Guru, Patent Law in India, n. 49 at 44.

54 WT/MIN/(01)DEC/2 20 November 2001: Doha WTO Ministerial 2001: TRIPS Declaration on the TRIPS Agreement and Public Health http:/www.wto.org/ english/thewto_e/minist_e/min01_e/mindee1_trips_e.htm (accessed July 11, 2011).

55 Goldstein, International Legal Materials on Intellectual Property, n. 8 at 32.

56 The TRIPS Agreement. http://www.wto.org/english/docs_e/legal_e/legal_e. htm (accessed April 11, 2011) 
and may require the applicant to indicate the best mode for carrying out the invention known to the inventor at the filling date, or where priority is claimed, at the priority date of the application. ${ }^{57}$

It would suffice to note that Article 29 of the TRIPS states that inventor knowledge required on the invention is at the filing date and any significant changes which occur aftermath can remain as a trade secret to the patentee. This is the reason under the Indian Patent Amendment Act 2005 under Section 3(d), the mere incremental innovation without any improvement to the known substance cannot be patented. Importantly, looking at Article 39.3 which requires marketing of pharmaceutical products to utilise new chemical entities, the submission if undisclosed test or other data shall protect such data against unfair commercial use, and members shall protect data against disclosure, exception occurs only when necessary to protect the public. Article 39.3 gives further importance to the rights of the patent holder in terms of disclosing the invention to the public as 'undisclosed data is protected under unfair commercial use.

The question is whether Article 39.3 will further reduce the effect of Article 29 on disclosing patentee's invention which is an important provision to exploit the patentee invention to produce generic drugs. This can be seen when multinational companies in India disproves hypothesis that strong intellectual property rights are important for their investments in R\&D. ${ }^{58}$ Through the observation in this study, Indian private sector started investing in $\mathrm{R} \& \mathrm{D}$ for developing new drugs since mid-1990s when TRIPS came into effect, as being new discovery research (NDDR) as a major objective. ${ }^{59}$ For example, Ranbaxy has set up its new research centre at Gurgaon and employs about 400 scientists, spent the largest amount of Rs2761 million in 2003-4 for R\&D among Indian companies. ${ }^{60}$ As argued by PHARMA, without patent protection the ability of the MNCs to invest in R\&D for developing new drugs will be seriously affected. ${ }^{61}$

57 The TRIPS Agreement. http://www.wto.org/english/tratop_e/trips_e/intel2_e. htm (accessed July 5, 2011).

58 Sudip Chaudhuri, The WTO and India's Pharmaceutical Industry: Patent Protection, TRIPS and Developing Countries (Oxford: Oxford University Press, 2005), 159.

59 Chaudhuri, The WTO and India's Pharmaceutical Industry, 159.

60 Chaudhuri, The WTO and India's Pharmaceutical Industry, 160.

61 Chaudhuri, The WTO and India's Pharmaceutical Industry, 322. 
The essential question is certainly not the need for strong patent system but a balanced and flexible patent system and TRIPS Agreement should be an important guideline in the implementation of national patent legislation which adopts the agreement that will meet country's public need, referring to the accessibility of medicines and affordability of medicines. It is also important to note after the Patent Amendment Act 2005, India as a member of WTO shall not be obliged to implement in its law a more extensive protection than what is required by this Agreement and members shall be free to determine the appropriate method of implementing the provisions of this Agreement within their own legal system and practice, as stated and in accordance with Article 1 of the TRIPS Agreement. ${ }^{62}$ In the author's view, Article 1 of the TRIPS Agreement refers to the TRIPS-PLUS obligations such as the controversy issue of data exclusivity and impliedly provides a defence against stronger intellectual property rights protection.

In summary, the author has emphasized throughout the study the issue of whether Section 3(d) is consistent with Article 27.1 of the TRIPS Agreement which prohibits discrimination as to the field of technology ${ }^{63}$ focusing mainly on the issue of having same standards for pharmaceutical industry while dealing with public health consideration. According to the author, Section 3(d) should not be merely read alone with Article 27.1 without giving much attention to Article 30 of the TRIPS Agreement on the limited exception to the exclusive rights given to the patentee.

Importantly, the author's question is whether India is enforcing its patent law after product patent implementation is giving too much attention to pre and post grant opposition compared to fully utilising TRIPS flexibilities such as compulsory licensing and Bolar provision. Based on the author's observation, it would suffice to note that the three requirements of patentability and, pre and post grant opposition are treated in isolation with TRIPS flexibilities. India is being aggressive in the pre and post-grant opposition as to whether it is because of the procedure to apply compulsory licensing

62 Correa, Carlos M. 2002. Intellectual Property Rights, the WTO and Developing Countries, The Trips Agreement and Policy Options. London, United States and Malaysia: Zed Books Third World Networks.

63 Hiroko Yamane, Interpreting TRIPS: Globalisation of Intellectual Property Rights and Access to Medicines (Oxford: Hart Publishing, 2011), 458. 
is cumbersome and difficult at the first place despite having grounds of compulsory licensing on anti-competitive practices, national working of patent and others.

Furthermore, looking at the case of Novartis $v$ Union of India and Roche $v$ Cipla,${ }^{64}$ to prevent evergreening of patents, the author is of the view that the decisions of the above cases are made to prevent patentee from keeping significant improvement of the patentee invention to themselves as a trade secret and disclosing only invention with no or less significance to the current invention, as their justification is further supported by Article 39.3 on the protection of undisclosed information.

Another legal challenge that India will face in the future is on the current issue of data exclusivity which India has to take into account in its legislation.. However, the TRIPS flexibilities the Bolar provision or called as 'the early working requirement' is certainly an exception to the TRIPS-PLUS obligations such as data exclusivity. The 'Bolar exception' is defined as the early working requirement which permits the use of an invention relating to a pharmaceutical product to conduct and obtain approval from the health authority before the expiration of the patent for the purpose of commercialization of generic therapeutic equivalent just after the expiration of a patent or speed up the entry of generic pharmaceutical products. ${ }^{65}$ The significance of Bolar provision can be seen in the case of Roche Products Inc vs Bolar Pharmaceuticals Co which denied the Bolar of the right to start to start FDA (Food and Drug Administration) approval process before the expiration of a patent. ${ }^{66}$ Data exclusivity prohibits authorities from relying on the originator data for the approval of subsequent products, and effectively delays the development and market approval of generics. ${ }^{67} \mathrm{In}$ the absence of provisions for reliance on the originator data, generic manufacturers would have to conduct their own clinical trials to establish the safety and efficacy of pharmaceuticals drugs. ${ }^{68}$ For example, United States provides data exclusivity for a period of five years and European

64 Yamane, Interpreting TRIPS, 449.

65 Comune, Health Innovation from and for the South, n. 46 at 28.

66 Comune, Health Innovation from and for the South, n. 46 at 28.

67 Prabodh Malhotra, Impact of TRIPS in India: An Access to Medicine Perspective (Great Britain: Palgrave MacMillan, 2010), 27.

68 Malhotra, Impact of TRIPS in India, 27. 
Union (EU) since reforms in 2004 provides data exclusivity for $8+2+1$ years. For instance actual market entry of generics will only be allowed after ten years of the launch of the originator product. Consequently, if new therapeutic indications of new uses of originator products are authorised, data exclusivity may be extended for another year. ${ }^{69}$ Subsequently, TRIPS Agreement does not explicitly mention the word data exclusivity as the TRIPS itself is also vague in defining the position on the protection of the submitted data. ${ }^{70}$ Article 39.3 is not clear on how data are to be protected and definition of 'unfair commercial use' is not provided in the TRIPS Agreement. ${ }^{71}$ It has certainly caught the author's attention when it was said that ambiguities in the Article have resulted in controversial interpretations by different parties with their own vested interests. ${ }^{72}$ Developing countries supported by public health advocates, NGOs and civil society groups came up with an important affirmation on data exclusivity stating that Article $39.3^{73}$ amount to data protection and to data exclusivity. ${ }^{74}$ However, the distinction between data protection and data exclusivity is not given and these two different terms can contribute to ambiguity. Data exclusivity will certainly be TRIPS-PLUS obligations for India as India is preparing to modify its Patents Act to provide data exclusivity for five years. However, India should bear in mind that obligation to implement provision that is only required by TRIPS Agreement and not those extra obligations such as TRIPS-PLUS provisions such as data exclusivity in order to subject to their bilateral/regional or free trade agreement. ${ }^{75}$

\section{Conclusion}

In conclusion, India as being the producer and exporting country, being a member of World Trade Organisation (WTO) certainly needs to comply with TRIPS Agreement by amending its national patent law accordingly, but without neglecting the important mechanism

69 Malhotra, Impact of TRIPS in India, 27.

70 Malhotra, Impact of TRIPS in India, 28.

71 Malhotra, Impact of TRIPS in India, 28.

72 Malhotra, Impact of TRIPS in India, 28.

73 Annex 1C Agreement on Trade Related Intellectual Property Rights, Article 39 of the TRIPS http://www.wto.org/english/docs e/legal e/legal e.htm (accessed April 2011).

74 Malhotra, Impact of TRIPS in India, n. 68 at 28.

75 Malhotra, Impact of TRIPS in India, n. 68 at 28. 
such as compulsory licensing and Bolar provision, which will be of benefit to India to improve accessibility and affordability of medicines. Indian Patent Amendment Act 2005 should not just be a medium for pre and post-grant opposition; though it cannot be denied it is important to prevent evergreening of patent and encouraging patentee to disclose significant invention. Furthermore, when the Managing Director and Chairman of Cipla (India's generic pharmaceutical company) Dr Yusuf K Hamied, being a chemist himself suggested a TRIPS North and TRIPS South, where north comprises of 600 million people in the developed world while the south comprises three billion people of the Third World, India should apply minimal or moderation requirement of TRIPS provisions into its legislation to achieve public health objectives. ${ }^{76}$ The effective use of compulsory licensing and clear interpretation will be important tools as legal weapons which will certainly assist India in promoting technology transfer, as India should avoid undermining and underutilizing the compulsory licensing system just for export purpose or to increase the economies of scale. For instance, India should set Brazil compulsory licensing as a good benchmark as strong provisions for compulsory licensing in the Brazil patent law were rightfully considered an important asset in their negotiation with pharmaceutical industry. ${ }^{77}$

Last but not least, amendment of the Indian Patent Law in 2005 complying with the TRIPS Agreement for the benefit of bilateral and free trade agreement and flexibilities given in the TRIPS itself which is believed to benefit generic pharmaceutical industry to improve accessibility and affordability of medicines, without being deceived into the TRIPS-PLUS obligations is a continuing legal challenge for India, as to get the best of both worlds is not easy as it seems. For instance, to implement minimum protection of intellectual property rights without implementing additional TRIPS obligations which is not mentioned in the TRIPS itself.

Interestingly, it was stated that India should resist removing any flexibility because any trade agreement which will lead India

76 See http://www.cipla.com/whatnew/news.htm (accessed March 5, 2011).

77 Basma I AbdelGafar, The Illusive Trade Off: Intellectual Property Rights, Innovation Systems and Egypt's Pharmaceutical Industry: Policy Options Under TRIPS: Reality or Illusion (Canada: University of Toronto Press, 2006), 174. 
not to be able to produce and will certainly effect the rest of the world.$^{78}$ Patent is something that is inevitable for India as being a member of WTO as can be seen with the implementation of product patent protection in 2005 to preserve their trade relations with other WTO members as even in TRIPS itself we cannot deny on the trade element which exist. One cannot prevent the use of patent and complying with TRIPS but India can ensure to utilize intellectual property rights in a minimum way accordingly for the development in their generic industry towards achieving public health objectives.

\section{Bibliography}

Abbott, Frederick M. "The Doha Declaration on the TRIPS Agreement and Public Health: Lighting A Dark Corner At The WTO." Journal of International Economic Law 5, no. 2 (2002): 469-505.

Abbott, Frederick M., and Rudolf V.Van Puymbroeck, Compulsory Licensing for Public Health: A Guide and Model Documents for Implementation of the Doha Declaration Paragraph 6 Decision. World Bank,Working Paper No. 61 Global HIV/ AIDS Program, 2005.Condon,

Abdel Gafar, Basma I. The Illusive Trade Off: Intellectual Property Rights, Innovation Systems and Egypt's Pharmaceutical Industry: Policy Options Under TRIPS: Reality or Illusion. Canada: University of Toronto Press, 2006.

Bellmann, Christophe, trans, Trading In Knowledge: Development Perspectives on TRIPS, Trade and Sustainability. United Kingdom, United States: EarthScan, 2003.

Bradly, and Tapen Sinha, Global Lessons from the AIDS Pandemic: Economic, Financial, Legal and Political Implications. Germany: Springer-Verlag Berlin Heidelberg, 2008.

78 Bhalla Nita, comment on "Millions Will Die if India Stops-AIDS Drugs," In United Nations Programme on HIV/AIDS (UNAIDS, comment posted July 5, 2011, http://www.bilaterals.org/spip.php?article19833 (accessed July 11, 2012). 
Chaudhuri, Sudip. The WTO and India's Pharmaceutical Industry: Patent Protection, TRIPS and Developing Countries. Oxford: Oxford University Press, 2005.

Comune, Maria. Health Innovation from and for the South? 'The TRIPS Agreement and pharmaceutical industry in India. LAP: Lambert Academic Publishing, 2010.

Correa, Carlos M. Intellectual Property Rights, the WTO and Developing Countries, The Trips Agreement and Policy Options. London, US and Malaysia: Zed Books: Third World Network, 2002.

Goldstein, Paul. International Legal Materials on Intellectual Property. United States: Foundation Press, 2006.

Kankala, Kalyan C, Arun K Narasani, and Radhakrishan Vinita. Indian Patent Law and Practice. Oxford: Oxford University Press, 2010.

Kuanpoth, Jakkrit. Patent Rights in Pharmaceuticals in Developing Countries: Major Challenges or the Future. United Kingdom and United States: Edward Elgar Publishing, 2010.

Malhotra, Prabodh. Impact of TRIPS in India: An Access to Medicine Perspective. Great Britain: Palgrave MacMillan, 2010.

Matthews, Duncan. Globalising Intellectual Property Rights: The TRIPS Agreement. Routledge: Warmick Studies in Globalisation, 2002.

Michael Sidibe Blog, Millions. http://www.bilaterals.org/spip. php?article19833/ (accessed July 11, 2012).

Pogge, Thomas, trans. Incentives for Global Public Health: Patent Law and Access to Essential Medicines. Cambridge: Cambridge University Press, 2010.

Rao,M.B., and Manjula Guru. Patent Law in India. Netherlands: Kluwer Law International, 2010. 
The Star Newspaper (Malaysia), 19 December 2010.

Yamane, Hiroko. Interpreting TRIPS: Globalisation of Intellectual Property Rights and Access to Medicines. Oxford: Hart Publishing, 2011. 